\title{
Determinants and Reference Ranges of Serum Immunoglobulins in Middle-Aged and Elderly Individuals: a Population-Based Study
}

\author{
Samer Raza Khan ${ }^{1,2} \cdot$ Layal Chaker, ${ }^{2,3}$ Mohammad Arfan Ikram ${ }^{2} \cdot$ Robin Patrick Peeters $^{2,3}$. \\ Petrus Martinus van Hagen ${ }^{1,4} \cdot$ Virgil Alain Silvester Hovestadt Dalm ${ }^{1,4,5}$
}

Received: 24 June 2021 / Accepted: 6 August 2021 / Published online: 10 September 2021

(c) The Author(s) 2021

\begin{abstract}
Purpose In clinical practice, currently one reference range for serum immunoglobulin (Ig) A, G, and M is applied to all adults, although various factors may influence Ig serum levels. Population-based data on determinants of $\operatorname{IgA}, \operatorname{IgG}$, and $\operatorname{IgM}$ and recommendations for subgroup specific reference ranges are lacking. We aimed to provide an overview of determinants of $\operatorname{IgA}, \mathrm{IgG}$, and IgM in community-dwelling middle-aged and elderly individuals and explore determinants that influence Ig reference ranges.

Methods Within the Rotterdam Study, we performed linear regression analyses for the association of demographic, lifestyle, and cardiovascular factors with serum $\operatorname{IgA}, \operatorname{IgG}$, and $\operatorname{IgM}$. We furthermore calculated Ig reference ranges (based on percentiles), both overall and within relevant subgroups.

Results We included 8768 participants (median age 62 years). IgA and IgG increased non-linearly with higher age $(P<.0001$ for both). Women had lower IgA (beta: $-0.24 ; 95 \%$ confidence interval $[95 \% \mathrm{CI}]:-0.29 ;-0.20$ ) and $\operatorname{IgG}$ (beta: $-0.33 ; 95 \%$ CI: $-0.44 ;-0.23$ ), but higher IgM levels (beta: 0.08 ; $95 \%$ CI: $0.04 ; 0.13$ ) than men. Former and particularly current smoking were associated with lower $\operatorname{IgA}$ and $\operatorname{IgG}$ (betas between -0.07 and -1.03 ). Higher alcohol consumption was associated with lower $\operatorname{IgG}$ (beta for heavy drinking: $-0.70 ; 95 \% \mathrm{CI}$ - $0.91 ;-0.48$ ). Corticosteroid use was associated with lower IgG (beta: $-1.12 ; 95 \% \mathrm{CI}:-1.58 ;-0.66)$. Associations with cardiovascular factors were heterogeneous and differed between sexes.

Conclusion Age, sex, smoking, alcohol consumption, corticosteroid use, and cardiovascular factors are determinants that should be considered when interpreting serum Ig levels in middle-aged and elderly individuals and may require adjusted reference ranges.
\end{abstract}

Keywords Immunoglobulin A · Immunoglobulin G · Immunoglobulin M · Epidemiologic factors · Reference values · Aging

Virgil Alain Silvester Hovestadt Dalm

v.dalm@erasmusmc.nl

1 Department of Internal Medicine, Division of Allergy \& Clinical Immunology, Erasmus University Medical Center, Rotterdam, the Netherlands

2 Department of Epidemiology, Erasmus University Medical Center, Rotterdam, the Netherlands

3 Department of Internal Medicine, Division of Endocrinology, Erasmus University Medical Center, Rotterdam, the Netherlands

4 Department of Immunology, Erasmus University Medical Center, Rotterdam, the Netherlands

5 Department of Internal Medicine, Erasmus University Medical Center, Dr. Molewaterplein 40, 3015 GD Rotterdam, the Netherlands

\section{Introduction}

Immunoglobulins (Igs) play an indispensable role in the defense against pathogenic microorganisms as well as in clearing aberrant cells, either directly or through interaction with other components of the immune system. In humans, the five primary classes of Igs are $\operatorname{IgA}$, IgG, IgM, IgD, and $\operatorname{IgE}(1)$. Individuals with low levels of serum $\operatorname{IgA}, \operatorname{IgG}$, and/ or IgM (hypogammaglobulinemia) are prone to infections and various other complications, including autoimmune disorders and malignancies, as can be seen in patients with common variable immunodeficiency, a primary immunodeficiency (PID) characterized by low levels of IgG with low IgA and/or low IgM levels [2-6]. On the other hand, 
elevated Ig levels have been associated with liver disease, connective tissue diseases, chronic infections, and malignancies among others [7].

Due to the heterogeneous clinical relevance of both low and high serum Ig levels, application of accurately defined reference ranges is essential. In children, age-specific reference ranges of serum Igs are routinely used in clinical practice [8]. For adults, current internationally used reference ranges are based on older studies that recommend one cutoff value for serum Igs, regardless of age or other potential determinants [9]. However, the employed assay, age, and sex are a few of the known factors to influence serum Ig levels [10-16]. Previous studies have shown that Ig levels vary within the adult population and that $\operatorname{IgA}$, IgG, and IgM levels change throughout aging, although results are conflicting on the direction of this association [17-21]. Additionally, other determinants of serum Ig levels in adults, such as lifestyle-related factors, biochemical markers, and drugs, have been identified as well. However, these studies had small sample sizes, only included categorized variables as determinant, did not perform formal regression analyses to test for an association, did not adjust for potential confounders, and/or did not include participants from the general population [22-25]. In a recent systematic review and meta-analysis, we showed that older age and male sex are associated with higher IgA and lower IgM levels. We furthermore reported that smoking and systemic corticosteroid use are associated with lower Ig levels, whereas probiotics, hypertension, alcohol consumption, and acute psychological stress are associated with higher Ig levels [26]. Other cardiovascular risk factors, including anthropometric and serum measurements, have been associated with serum Igs as well $[22,26]$.

However, no overview exists of potential determinants of serum Ig levels in a general, aging population. We therefore investigated the association of common demographic, lifestyle-related, and cardiovascular risk factors with serum Ig levels in a general population cohort of middle-aged and elderly individuals. Determinants were selected based on biological plausibility, previous literature, and availability in our study cohort. Furthermore, we aimed to define reference ranges of serum $\operatorname{IgA}, \mathrm{IgG}$, and $\operatorname{IgM}$ in our cohort and assess whether reference ranges differ between subgroups of identified relevant determinants.

\section{Methods}

\section{Study Design and Participants}

This study was embedded in the Rotterdam Study (RS), a large ongoing prospective population-based cohort study including middle-aged and elderly participants from
Ommoord, Rotterdam, the Netherlands. Within the RS epidemiological research is performed in various fields, including cardiovascular, endocrine, neuropsychiatric, and respiratory diseases. The RS started in 1990 and had included 14,926 participants by the end of 2008. The RS initially comprised three independent cohorts (RS I, RS II, RS III) that each include re-examination cycles every 3-6 years. In 2016, the fourth cohort started. In addition to the examinations at the research center in Ommoord and home interviews, participants are followed for comorbidities and mortality through continuous automated linkage of the study database with general practitioners' (GPs') records. The RS has been approved by the Medical Ethics Committee of the Erasmus Medical Centre (registration number MEC 02.1015) and the Dutch Ministry of Health, Welfare and Sports (Population Screening Act WBO, license number 1071272-159,521-PG). The RS Personal Registration Data collection is filed with the Erasmus Medical Centre Data Protection Officer under registration number EMC1712001. The RS has been entered into the Netherlands National Trial Register and into the World Health Organization (WHO) International Clinical Trials Registry Platform under shared catalogue number NTR6831. Details of the RS have been previously published [27].

For this study, we included all participants from three independent RS cohorts with serum measurements of $\operatorname{IgA}$, $\mathrm{IgG}$, and/or IgM at baseline and written informed consent for follow-up $(n=8768)$.

\section{Assessment of Serum Immunoglobulins}

An immunoturbidimetric assay (Tina-quant ${ }^{\circledR} \operatorname{Ig} \mathrm{A} / \mathrm{IgG} /$ IgM Gen. 2, Roche Diagnostics GmbH, Mannheim, Germany) was implemented to measure serum $\operatorname{IgA}, \operatorname{IgG}$, and IgM in grams per liter $(\mathrm{g} / \mathrm{L})$. All measurements were conducted between 2016 and 2018 in all available baseline samples stored at $-80{ }^{\circ} \mathrm{C}$. According to manufacturer's protocol, the recommended reference ranges for this assay in adults were $0.7-4.0 \mathrm{~g} / \mathrm{L}$ for $\operatorname{IgA}, 7.0-16.0 \mathrm{~g} / \mathrm{L}$ for $\mathrm{IgG}$, and $0.4-2.3 \mathrm{~g} / \mathrm{L}$ for $\mathrm{IgM}$. These reference ranges are based on the certified reference material for immunochemical measurements of 14 human serum proteins (CRM 470). CRM 470 is an international secondary reference material for adults without provision of age-specific reference ranges [28]. Coefficients of variation (CV) were calculated across all batches (to test assay precision) and between each batch (to identify time trends or batch effects). The $\mathrm{CV}$ across batches varied from 1.11 to $5.25 \%$ for each Ig. The CV between batches for each Ig varied from 0.61 to $2.85 \%$. 


\section{Baseline Measurements of Potential Determinants and Other Covariates}

Smoking status and alcohol consumption were established through questionnaires. Smoking status was defined as current, former, or never smoker. Alcohol consumption was measured in grams per day and was categorized according to WHO guidelines. A daily consumption of $0-10 \mathrm{~g} / \mathrm{day}$ was considered mild, 10-20 g/day moderate, and $>20 \mathrm{~g} /$ day as heavy. Physical activity was reported in metabolic equivalent of task (MET) hours per week and was assessed through validated questionnaires [29, 30]. Anthropometric data was collected during physical examination. Body mass index (BMI) was calculated as weight divided by squared height $\left(\mathrm{kg} / \mathrm{m}^{2}\right)$. Waist and hip circumference were measured in centimeters. Blood pressure was measured twice at the right arm in sitting position and the mean value was used for analyses. Hypertension was defined as a blood pressure of $\geq 140 / 90 \mathrm{~mm} \mathrm{Hg}$ or as the use of blood pressure lowering medication for the indication of hypertension. Fasting serum samples were collected at the research center in Ommoord. Glucose was measured using the glucose hexokinase method and expressed in millimoles per liter. Triglycerides, HDL, and total cholesterol were measured in millimoles per liter by an automated enzymatic procedure. C-reactive protein (CRP) was measured through an immunoturbidimetric assay in milligrams per liter. Use of oral corticosteroids (ATC code H02), antiepileptic drugs (ATC code N03), and angiotensinconverting enzyme (ACE) inhibitors (ATC code C09) was established during home interviews.

Information on baseline cardiovascular and circulatory diseases (comprising myocardial infarction, revascularization, and stroke) was retrieved through home interviews, linkage with the Dutch Hospital Data (LMR; a national registry of all hospitalizations in the Netherlands), letters of medical specialists, and screening of medical records of GPs. Information was retrieved by trained research assistants and verified by trained independent research physicians according to predefined clinical criteria. Baseline cancer cases were established by two independent physicians based on linkage with the LMR, PALGA (a regional registry of pathology reports), and medical records of GPs. Baseline chronic respiratory disease (chronic obstructive pulmonary disease) was based on pre-bronchodilator spirometry at the research center in Ommoord, or on medical records of respiratory physicians or GPs.

\section{Statistical Analyses}

The association between potential determinants and serum Ig levels was assessed by multiple linear regression models and shown in plots and tables. We standardized continuous determinants for comparison and used two models to examine the association. The first model was unadjusted, and in the second model we adjusted for age, sex, BMI, smoking status, alcohol consumption, and hypertension based on biological plausibility. Predefined stratified analyses were performed by sex. Non-linearity of the association between continuous determinants and Igs was assessed by ordinary least squares linear regression models with restricted cubic splines with 3 knots. Furthermore, residual plots were made for all associations and these did not show heteroscedasticity. Possible outliers were excluded in a sensitivity analysis. The percentage of missing values was $\leq 2.2 \%$ for all determinants, with the exception of waist and hip circumference (5.3\%), physical activity (14.1\%), and alcohol consumption (20.4\%). However, complete case analyses showed similar results for these determinants. We applied multivariate imputation by chained equations ( 5 imputations, 10 iterations) to impute missing values. Reference ranges were defined as the 2.5th and 97.5th percentiles in accordance with widely applied practice in clinical chemistry [31]. Reference ranges of serum Igs were computed for all included participants and for men and women separately. Reference ranges were also computed after exclusion of participants with the top three most burdensome diseases in the elderly, i.e., cardiovascular and circulatory diseases, cancer, and chronic respiratory disease [32]. We furthermore computed reference ranges for 5-year age categories ranging from 45 to $\geq 85$ years and for participants $<65$ or $\geq 65$ years. Reference ranges were also stratified by other determinants if these were significantly associated with serum Ig levels. All analyses were performed in $\mathrm{R}$ statistical software versions 3.6.3 and 4.0.0.

\section{Results}

\section{Study Population Characteristics}

We included 8768 participants with a median age of 62.2 years (interquartile range, IQR: 57.4-70.7) and of whom 57\% were women. Of these 8768 participants, 8767 had IgA measurements, 8757 had IgG measurements, and 8763 had IgM measurements. Full study population characteristics are shown in Table 1 . The median values of $\mathrm{IgA}, \mathrm{IgG}$, and $\mathrm{IgM}$ were $2.10 \mathrm{~g} / \mathrm{L}, 9.70 \mathrm{~g} / \mathrm{L}$, and $0.85 \mathrm{~g} / \mathrm{L}$ respectively.

\section{Determinants of Immunoglobulins}

\section{Demographic Factors}

The associations of age with $\operatorname{IgA}$ and $\operatorname{IgG}(P<0.0001$ for both) were non-linear, J- and U-shaped, respectively (Fig. 1). We did not find an association between age and 
Table 1 Study population characteristics for 8768 Rotterdam Study participants with immunoglobulin measurements and informed consent for follow-up

\begin{tabular}{|c|c|}
\hline Covariate & $N(\%)^{\mathrm{a}}$ \\
\hline IgA, g/L, median (IQR) & $2.10(1.57-2.78)$ \\
\hline IgG, g/L, median (IQR) & $9.70(8.30-11.20)$ \\
\hline IgM, g/L, median (IQR) & $0.85(0.59-1.23)$ \\
\hline Age, years, median (IQR) & $62.2(57.4-70.7)$ \\
\hline Sex, female & $4995(57)$ \\
\hline \multicolumn{2}{|l|}{ Smoking status } \\
\hline - Current & $-1712(19.5)$ \\
\hline - Former & $-4155(47.4)$ \\
\hline - Never & $-2901(33.1)$ \\
\hline \multicolumn{2}{|l|}{ Alcohol consumption ${ }^{\mathrm{b}}$} \\
\hline - None & $-1510(17.2)$ \\
\hline - Mild (0-10 g/day) & $-4673(53.3)$ \\
\hline - Moderate (10-20 g/day) & $-1456(16.6)$ \\
\hline - Heavy (> 20 g/day) & $-1129(12.9)$ \\
\hline $\begin{array}{l}\text { Standardized physical activity, MET hours/ } \\
\text { week, median (IQR) }\end{array}$ & $-0.16(-0.67$ to 0.53$)$ \\
\hline BMI, $\mathrm{kg} / \mathrm{m}^{2}$, median $(\mathrm{IQR})$ & $26.8(24.5-29.6)$ \\
\hline Waist circumference, cm, mean (SD) & $93.8(12.2)$ \\
\hline Hip circumference, cm, mean (SD) & $104.3(9.0)$ \\
\hline Hypertension & $5,345(61)$ \\
\hline Serum glucose, mmol/L, median (IQR) & $5.50(5.10-6.00)$ \\
\hline Total serum cholesterol, $\mathrm{mmol} / \mathrm{L}$, mean $(\mathrm{SD})$ & $5.70(1.03)$ \\
\hline $\begin{array}{l}\text { Serum HDL cholesterol, mmol/L, mean } \\
\text { (SD) }\end{array}$ & $1.40(0.41)$ \\
\hline Serum triglycerides, $\mathrm{mmol} / \mathrm{L}$, median (IQR) & $1.33(1.00-1.82)$ \\
\hline Serum CRP, mg/L, median (IQR) & $1.50(0.60-3.40)$ \\
\hline Use of systemic corticosteroids & $104(1.2)$ \\
\hline Use of antiepileptic drugs & $120(1.4)$ \\
\hline Use of ACE inhibitors & $1,168(13.3)$ \\
\hline
\end{tabular}

$\operatorname{IgA}$, immunoglobulin A; $\operatorname{Ig} G$, immunoglobulin $\mathrm{G}$; $\operatorname{Ig} M$, immunoglobulin $\mathrm{M} ; I Q R$, interquartile range; $M E T$, metabolic equivalent of task; $B M I$, body mass index; HDL, high-density lipoprotein; $C R P, \mathrm{C}$-reactive protein; $A C E$, angiotensin-converting enzyme

${ }^{a}$ Unless stated otherwise

${ }^{\mathrm{b}} 10 \mathrm{~g}$ alcohol/day is equivalent to one alcoholic beverage according to World Health Organization guidelines

IgM (Table 2). Women had lower IgA (beta: $-0.24 ; 95 \%$ confidence interval $[95 \% \mathrm{CI}]:-0.29 ;-0.20)$ and $\mathrm{IgG}$ (beta: -0.33 ; 95\% CI: $-0.44 ;-0.23$ ) levels compared to men, whereas IgM was higher in women (beta: $0.08 ; 95 \%$ CI: 0.04;0.13) (Table 2, Fig. 1).

\section{Lifestyle Factors}

Former compared to never smokers had lower serum $\operatorname{IgA}$ (beta: $-0.07 ; 95 \% \mathrm{CI}:-0.12 ;-0.02$ ) and IgG (beta: -0.25 ; $95 \% \mathrm{CI} ;-0.37 ;-0.13)$ levels. Current smoking was associated with even lower levels of $\operatorname{IgA}$ (beta: -0.29 ;
95\% CI: $-0.35 ;-0.22$ ) and $\operatorname{IgG}$ (beta: $-1.03 ; 95 \%$ CI: $-1.17 ;-0.88$ ) than never smoking (Table 2, Fig. 2). Alcohol consumption was also associated with lower IgG levels, particularly heavy drinking (beta: -0.70 ; 95\% CI: $-0.91 ;-0.48$ ) (Table 2, Fig. 2). Physical activity was associated with lower serum $\operatorname{IgA}$ (beta: -0.04 ; 95\% CI: $-0.06 ;-0.01$ ) and $\mathrm{IgG}$ (beta: $-0.08 ; 95 \%$ CI: $-0.14 ;-0.01$ ) levels (Table 2, Fig. 2).

\section{Cardiovascular Risk Factors}

Higher BMI was associated with higher serum $\operatorname{IgA}$ (beta: 0.05; 95\% CI: $0.03 ; 0.07$ ) and IgG (beta: $0.06 ; 95 \% \mathrm{CI}$ : $0.01 ; 0.12$ ) levels (Table 2, Fig. 3). Higher waist and hip circumferences were associated with higher IgA (beta: $0.07 ; 95 \%$ CI: $0.02 ; 0.12$ ) and higher IgG (beta: $0.15 ; 95 \%$ CI: $0.06 ; 0.23$ ) levels respectively (Table 2 ). We found negative associations of total serum cholesterol with IgA (beta: -0.06 ; 95\% CI: $-0.08 ;-0.04$ ) and IgG (beta: -0.18 ; 95\% CI: $-0.23 ;-0.13$ ), of HDL cholesterol with $\operatorname{IgA}$ (beta: $-0.07 ; 95 \%$ CI: $-0.10 ;-0.05$ ) and $\operatorname{IgM}$ (beta: -0.03 ; $95 \% \mathrm{CI}:-0.05 ;-0.01)$, and of serum triglycerides with IgG (beta: -0.06 ; 95\% CI: $-0.12 ;-0.01$ ) (Table 2). Some cardiovascular risk factors were non-linearly associated with serum Igs (Figs. S1-3). Although hypertension was associated with higher IgA and IgG, but lower IgM levels, these associations lost significance in the multivariate model (Table 2, Fig. 3). Higher serum CRP levels were associated with a non-linear increase of IgA, IgG, and IgM (Figs. S1-3).

\section{Medication}

IgA levels were lower in users of antiepileptic drugs (beta: $-0.20 ; 95 \% \mathrm{CI}:-0.40 ;-0.01$ ), while $\mathrm{IgG}$ was lower in participants that used systemic corticosteroids (beta: -1.12 ; 95\% CI: - 1.58;-0.66) (Table 2). No associations were found for ACE-inhibitors with Igs (Table 2).

A graphic overview of identified determinants is presented in Fig. S4. Exclusion of outliers in the residual plots did not change any effect estimates (data not shown).

\section{Determinants Stratified by Sex}

Analyses stratified by sex are shown in Table S1 and Figs. S5 and S6. Most notable differences include the associations with age, smoking, and corticosteroid use.

The association of age with IgA showed a J-shaped increase in women, whereas in men this association was linear (beta: 0.14; 95\% CI: 0.10;0.18) (Table S1, Fig. S5). The association of age with IgG was J-shaped in men and U-shaped in women (Table S1, Fig. S6). Women displayed a negative association of age with IgM (beta: -0.06 ; $95 \%$ 

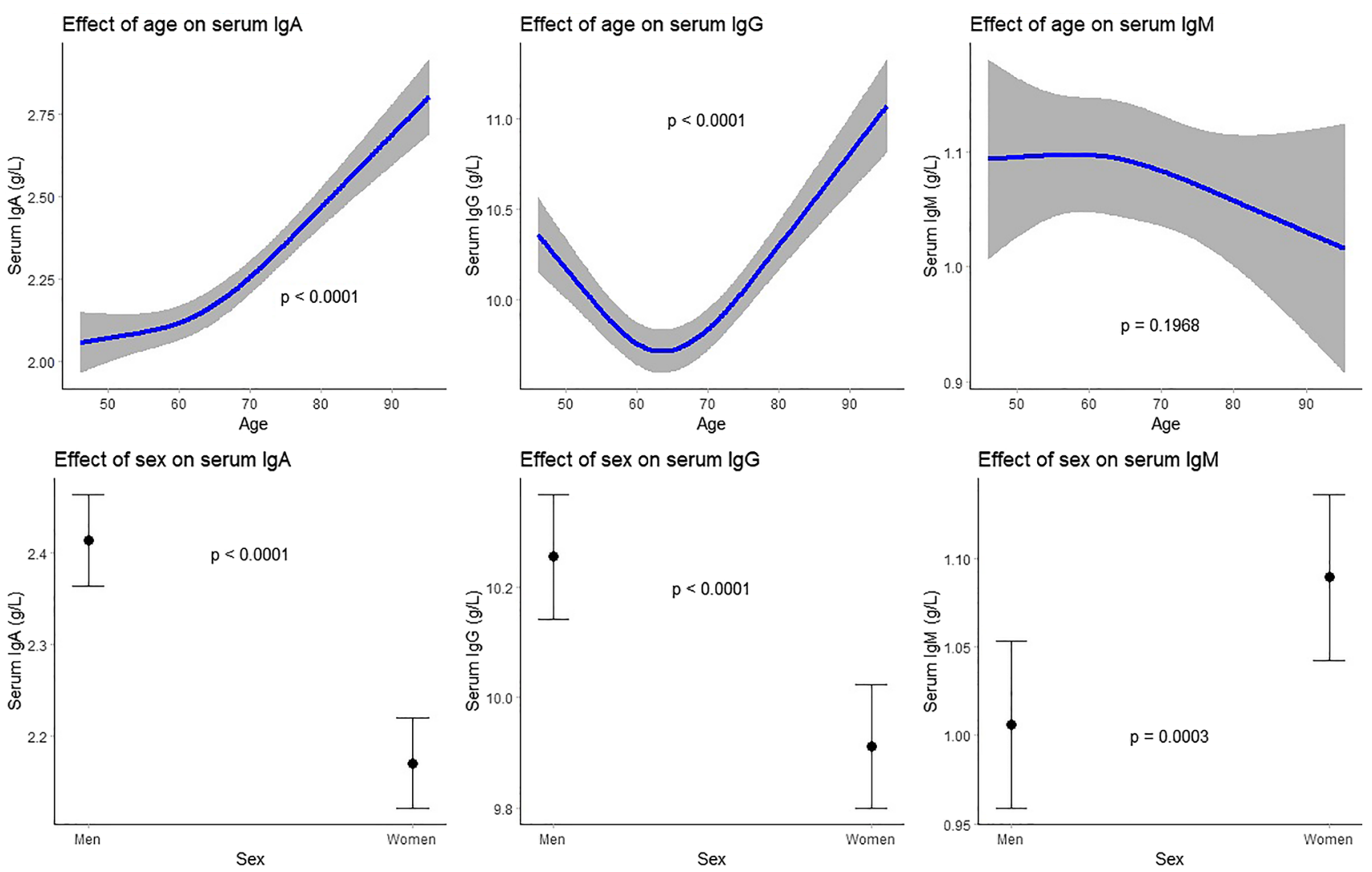

Fig. 1 Association between demographic factors and serum immunoglobulin $(\mathrm{g} / \mathrm{L})$ levels. Top 3 plots depict association between age and serum $\operatorname{IgA}, \operatorname{IgG}$, and $\operatorname{IgM}$ respectively with corresponding $95 \%$ confidence intervals. The associations have been adjusted for sex, BMI, smoking status, alcohol consumption, and hypertension. Bot-

CI: $-0.08 ;-0.03)$, while a positive association was found in men (beta: $0.05 ; 95 \%$ CI: $0.01 ; 0.09)$ (Table S1).

Smoking was associated with lower serum IgG in both sexes, but this was more profound in female current smokers (beta: -1.17 ; 95\% CI: $-1.36 ;-0.97)$. Use of systemic corticosteroids was associated with lower serum IgG in both sexes and lower serum IgA in men (beta: -0.35 ; $95 \%$ CI: $-0.71 ;-0.00)$ (Table S1).

\section{Reference ranges of Immunoglobulins}

The overall reference ranges in our population were $0.86-4.76 \mathrm{~g} / \mathrm{L}$ for $\operatorname{IgA}, 6.20-15.10 \mathrm{~g} / \mathrm{L}$ for $\mathrm{IgG}$, and $0.28-2.64 \mathrm{~g} / \mathrm{L}$ for IgM. In comparison, the assay's recommended reference ranges were $0.7-4.0 \mathrm{~g} / \mathrm{L}$ for $\mathrm{IgA}$, 7.0-16.0 g/L for IgG, and $0.4-2.3 \mathrm{~g} / \mathrm{L}$ for $\mathrm{IgM}$.

Exclusion of the top three most burdensome diseases in the elderly $(n=1752)$ did not change reference ranges (Table 3). Women had slightly lower reference ranges for $\operatorname{Ig} \mathrm{A}(0.84-4.58)$ and $\operatorname{IgG}(6.10-15.10)$, but higher for $\operatorname{IgM}$ tom 3 plots depict association between sex and serum $\operatorname{IgA}, \operatorname{IgG}$, and IgM respectively with corresponding $95 \%$ confidence intervals. The associations have been adjusted for age, BMI, smoking status, alcohol consumption, and hypertension. IgA, immunoglobulin A; IgG, immunoglobulin G; IgM, immunoglobulin M; BMI, body mass index

(0.30-2.75) compared to men. No clear trend was observed for age, but overall the upper limit of the reference range of all Igs seemed to increase in the older age groups (Table 3 ). When stratified by smoking status, $\operatorname{IgA}(0.81-4.35)$ and especially IgG (5.80-13.90) were lower in the current smokers (Table 3) and additional analyses showed that this mainly held for female current smokers (Table S2). Alcohol consumption did not influence reference ranges, although heavy drinkers ( $>20 \mathrm{~g} /$ day) had higher IgA levels (0.98-5.13) (Table 3).

For IgA, our reference ranges compared to the assay's recommended reference ranges yielded fewer participants with hypergammaglobulinemia (214 vs 535 ), but more with hypogammaglobulinemia (213 vs 98 ). For IgG however, our reference ranges yielded more participants with hypergammaglobulinemia (214 vs 133) and fewer with hypogammaglobulinemia (201 vs 593), whereas for IgM fewer participants were classified with either hypergammaglobulinemia (218 vs 344) or hypogammaglobulinemia (196 vs 715) (Fig. 4). When taking participants with hypo- and hypergammaglobulinemia together, the largest discrepancy 
Table 2 Association between standardized covariates and serum immunoglobulin levels

\begin{tabular}{|c|c|c|c|c|c|c|}
\hline \multirow[t]{3}{*}{ Covariate } & \multicolumn{2}{|l|}{$\operatorname{IgA}(g / L)$} & \multicolumn{2}{|l|}{$\operatorname{IgG}(\mathrm{g} / \mathrm{L})$} & \multicolumn{2}{|l|}{$\operatorname{IgM}(\mathrm{g} / \mathrm{L})$} \\
\hline & \multicolumn{2}{|l|}{ Beta $(95 \%$ CI) } & \multicolumn{2}{|l|}{ Beta $(95 \%$ CI) } & \multicolumn{2}{|l|}{ Beta $(95 \%$ CI) } \\
\hline & Model 1 & Model 2 & Model 1 & Model 2 & Model 1 & Model 2 \\
\hline \multicolumn{7}{|l|}{ Demographic factors } \\
\hline Age & $\begin{array}{l}\text { Non-linear } \\
\qquad(P<.0001)\end{array}$ & $\begin{array}{l}\text { Non-linear } \\
\qquad(P<.0001)\end{array}$ & $\begin{array}{l}\text { Non-linear } \\
\qquad(P<.0001)\end{array}$ & $\begin{array}{l}\text { Non-linear } \\
\qquad(P<.0001)\end{array}$ & $-0.02(-0.04 ; 0.01)$ & $-0.01(-0.04 ; 0.01)$ \\
\hline \multicolumn{7}{|l|}{ Sex } \\
\hline (female vs male) & $\begin{array}{l}-0.21 \\
\quad(-0.26 ;-0.17)\end{array}$ & $\begin{array}{l}-0.24 \\
\quad(-0.29 ;-0.20)\end{array}$ & $\begin{array}{l}-0.13 \\
\quad(-0.23 ;-0.03)\end{array}$ & $\begin{array}{l}-0.33 \\
(-0.44 ;-0.23)\end{array}$ & $0.09(0.04 ; 0.13)$ & $0.08(0.04 ; 0.13)$ \\
\hline \multicolumn{7}{|l|}{ Lifestyle factors } \\
\hline \multicolumn{7}{|l|}{ Smoking status } \\
\hline (former vs never) & $-0.01(-0.06 ; 0.04)$ & $\begin{array}{l}-0.07 \\
\quad(-0.12 ;-0.02)\end{array}$ & $\begin{array}{l}-0.27 \\
(-0.38 ;-0.15)\end{array}$ & $\begin{array}{l}-0.25 \\
(-0.37 ;-0.13)\end{array}$ & $-0.01(-0.05 ; 0.04)$ & $0.02(-0.03 ; 0.07)$ \\
\hline (current vs never) & $\begin{array}{l}-0.31 \\
\quad(-0.37 ;-0.24)\end{array}$ & $\begin{array}{l}-0.29 \\
\quad(-0.35 ;-0.22)\end{array}$ & $\begin{array}{l}-1.12 \\
\quad(-1.26 ;-0.98)\end{array}$ & $\begin{array}{l}-1.03 \\
\quad(-1.17 ;-0.88)\end{array}$ & $-0.01(-0.07 ; 0.05)$ & $-0.00(-0.06 ; 0.06)$ \\
\hline \multicolumn{7}{|l|}{ Alcohol consumption } \\
\hline (mild vs none) & $-0.05(-0.13 ; 0.04)$ & $-0.02(-0.10 ; 0.07)$ & $\begin{array}{l}-0.21 \\
\quad(-0.36 ;-0.06)\end{array}$ & $\begin{array}{l}-0.19 \\
(-0.34 ;-0.04)\end{array}$ & $0.02(-0.04 ; 0.08)$ & $0.02(-0.05 ; 0.08)$ \\
\hline (moderate vs none) & $-0.01(-0.11 ; 0.08)$ & $-0.01(-0.10 ; 0.09)$ & $\begin{array}{l}-0.52 \\
(-0.71 ;-0.32)\end{array}$ & $\begin{array}{l}-0.48 \\
(-0.68 ;-0.29)\end{array}$ & $-0.01(-0.10 ; 0.07)$ & $-0.00(-0.09 ; 0.08)$ \\
\hline (heavy vs none) & $0.07(-0.03 ; 0.16)$ & $0.02(-0.08 ; 0.12)$ & $\begin{array}{l}-0.71 \\
\quad(-0.91 ;-0.50)\end{array}$ & $\begin{array}{l}-0.70 \\
(-0.91 ;-0.48)\end{array}$ & $-0.07(-0.16 ; 0.01)$ & $-0.05(-0.13 ; 0.04)$ \\
\hline Physical activity & $\begin{array}{l}\text { Non-linear } \\
\quad(P<.0001)\end{array}$ & $\begin{array}{l}-0.04 \\
\quad(-0.06 ;-0.01)\end{array}$ & $\begin{array}{l}-0.10 \\
\quad(-0.16 ;-0.04)\end{array}$ & $\begin{array}{l}-0.08 \\
\quad(-0.14 ;-0.01)\end{array}$ & $0.01(-0.01 ; 0.04)$ & $0.00(-0.02 ; 0.03)$ \\
\hline \multicolumn{7}{|c|}{ Cardiovascular risk factors } \\
\hline BMI & $0.05(0.02 ; 0.07)$ & $0.05(0.03 ; 0.07)$ & $0.09(0.04 ; 0.14)$ & $0.06(0.01 ; 0.12)$ & $-0.02(-0.04 ; 0.00)$ & $-0.02(-0.04 ; 0.00)$ \\
\hline Waist circumference & $0.11(0.08 ; 0.13)$ & $0.07(0.02 ; 0.12)$ & $\begin{array}{l}\text { Non-linear } \\
\qquad(P=0.0180)\end{array}$ & $\begin{array}{l}-0.13 \\
(-0.24 ;-0.02)\end{array}$ & $\begin{array}{l}-0.04 \\
(-0.06 ;-0.02)\end{array}$ & $-0.03(-0.07 ; 0.01)$ \\
\hline Hip circumference & $0.00(-0.02 ; 0.02)$ & $-0.02(-0.06 ; 0.02)$ & $0.10(0.05 ; 0.15)$ & $0.15(0.06 ; 0.23)$ & $0.00(-0.02 ; 0.02)$ & $0.03(-0.00 ; 0.07)$ \\
\hline \multicolumn{7}{|l|}{ Hypertension } \\
\hline (yes vs no) & $0.15(0.11 ; 0.20)$ & $0.02(-0.03 ; 0.07)$ & $0.19(0.09 ; 0.29)$ & $0.03(-0.08 ; 0.14)$ & $\begin{array}{l}-0.05 \\
\quad(-0.09 ;-0.00)\end{array}$ & $-0.03(-0.07 ; 0.02)$ \\
\hline Glucose & $0.10(0.08 ; 0.12)$ & $\begin{array}{l}\text { Non-linear } \\
\qquad(P<.0001)\end{array}$ & $-0.04(-0.09 ; 0.01)$ & $\begin{array}{l}\text { Non-linear } \\
\qquad(P=0.0001)\end{array}$ & $\begin{array}{l}\text { Non-linear } \\
\qquad(P=0.0170)\end{array}$ & $0.00(-0.02 ; 0.03)$ \\
\hline Cholesterol & $\begin{array}{l}-0.07 \\
\quad(-0.10 ;-0.05)\end{array}$ & $\begin{array}{l}-0.06 \\
\quad(-0.08 ;-0.04)\end{array}$ & $\begin{array}{l}-0.21 \\
\quad(-0.26 ;-0.16)\end{array}$ & $\begin{array}{l}-0.18 \\
\quad(-0.23 ;-0.13)\end{array}$ & $\begin{array}{l}\text { Non-linear } \\
\quad(P=0.0019)\end{array}$ & $\begin{array}{l}\text { Non-linear } \\
\quad(P=0.0006)\end{array}$ \\
\hline HDL cholesterol & $\begin{array}{l}-0.10 \\
(-0.13 ;-0.08)\end{array}$ & $\begin{array}{l}-0.07 \\
\quad(-0.10 ;-0.05)\end{array}$ & $\begin{array}{l}-0.22 \\
(-0.27 ;-0.17)\end{array}$ & $\begin{array}{l}\text { Non-linear } \\
\qquad(\mathrm{P}<.0001)\end{array}$ & $-0.00(-0.02 ; 0.02)$ & $-0.03(-0.05 ;-0.01)$ \\
\hline Triglycerides & $0.02(0.00 ; 0.05)$ & $\begin{array}{l}\text { Non-linear } \\
\quad(P=0.0432)\end{array}$ & $\begin{array}{l}-0.05 \\
\quad(-0.10 ;-0.00)\end{array}$ & $\begin{array}{l}-0.06 \\
\quad(-0.12 ;-0.01)\end{array}$ & $\begin{array}{l}\text { Non-linear } \\
\quad(P=0.0058)\end{array}$ & $\begin{array}{l}\text { Non-linear } \\
\qquad(P=0.0651)\end{array}$ \\
\hline CRP & $\begin{array}{l}\text { Non-linear } \\
\qquad(P<.0001)\end{array}$ & $\begin{array}{l}\text { Non-linear } \\
\qquad(P<.0001)\end{array}$ & $\begin{array}{l}\text { Non-linear } \\
\quad(P<.0001)\end{array}$ & $\begin{array}{l}\text { Non-linear } \\
\qquad(P<.0001)\end{array}$ & $\begin{array}{l}\text { Non-linear } \\
\quad(P=0.0061)\end{array}$ & Non-linear $(P<.0001)$ \\
\hline \multicolumn{7}{|l|}{ Medication } \\
\hline \multicolumn{7}{|l|}{ Glucocorticoids } \\
\hline (yes vs no) & $-0.01(-0.22 ; 0.20)$ & $-0.12(-0.32 ; 0.09)$ & $\begin{array}{l}-0.96 \\
(-1.43 ;-0.49)\end{array}$ & $\begin{array}{l}-1.12 \\
\quad(-1.58 ;-0.66)\end{array}$ & $-0.03(-0.31 ; 0.26)$ & $-0.01(-0.30 ; 0.27)$ \\
\hline \multicolumn{7}{|l|}{ Anti-epileptics } \\
\hline (yes vs no) & $-0.19(-0.39 ; 0.00)$ & $\begin{array}{l}-0.20 \\
\quad(-0.40 ;-0.01)\end{array}$ & $-0.35(-0.78 ; 0.09)$ & $-0.40(-0.83 ; 0.03)$ & $0.10(-0.17 ; 0.36)$ & $0.10(-0.16 ; 0.37)$ \\
\hline \multicolumn{7}{|l|}{ ACE inhibitors } \\
\hline (yes vs no) & $0.10(0.03 ; 0.16)$ & $-0.00(-0.07 ; 0.06)$ & $0.13(-0.02 ; 0.28)$ & $-0.02(-0.17 ; 0.14)$ & $-0.04(-0.10 ; 0.02)$ & $-0.01(-0.07 ; 0.06)$ \\
\hline
\end{tabular}

Model 1 is unadjusted. Model 2 is adjusted for age, sex, BMI, smoking status, alcohol consumption, and hypertension

$I g A$, immunoglobulin A; $I g G$, immunoglobulin G; $I g M$, immunoglobulin M; $95 \% C I$, 95\% confidence interval; $B M I$, body mass index; $H D L$, high density lipoprotein; $C R P, \mathrm{C}$-reactive protein; $A C E$, angiotensin-converting enzyme 

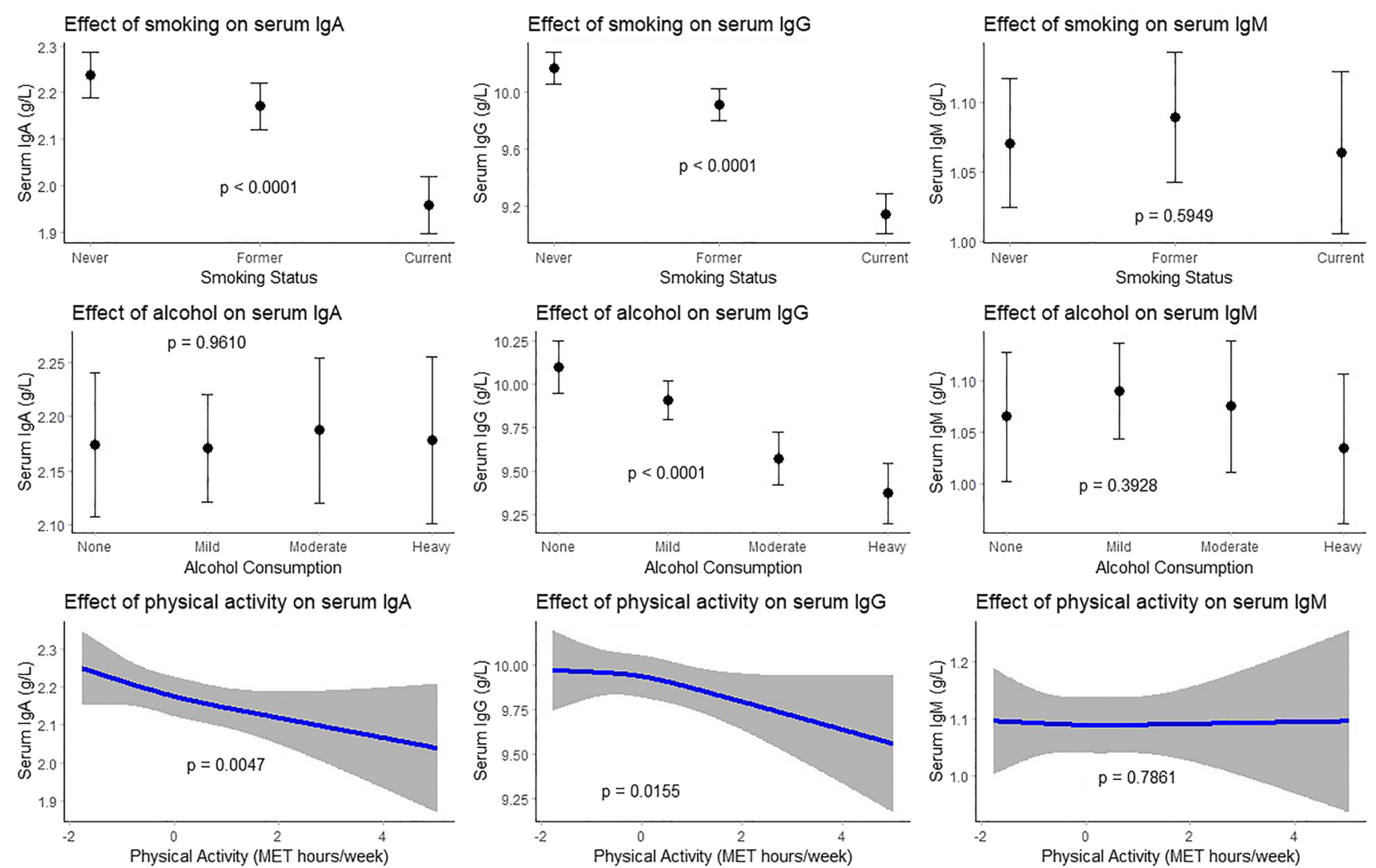

Fig. 2 Association between lifestyle factors and serum immunoglobulin $(\mathrm{g} / \mathrm{L})$ levels. Top 3 plots depict association between smoking status and serum $\operatorname{IgA}, \operatorname{IgG}$, and $\operatorname{IgM}$ respectively with corresponding 95\% confidence intervals. The associations have been adjusted for age, sex, BMI, alcohol consumption, and hypertension. Middle 3 plots depict association between alcohol consumption and serum $\mathrm{IgA}, \mathrm{IgG}$, and $\mathrm{IgM}$ respectively with corresponding $95 \%$ confidence intervals. The associations have been adjusted for age, sex, BMI, smoking status, and hypertension. Mild consumption was defined as 0-10 g/day, moderate consumption as 10-20 g/day, and heavy con-

between assay recommended and calculated reference ranges for the entire study population was found for IgM (Table 4). The number of participants with Ig levels in- or outside the reference range for the assay recommended vs our calculated age- and sex-specific reference ranges are depicted in Table S3. For IgA and IgM, the discrepancy was largest in participants $\geq 65$ years and in men, whereas for IgG the reference ranges particularly differed in participants $<65$ years and in women.

\section{Discussion}

We identified age, sex, smoking status, alcohol consumption, physical activity, BMI, serum cholesterol, serum CRP, and systemic corticosteroid use as potential determinants of serum IgA, IgG, and IgM in our general population cohort sumption as $>20 \mathrm{~g} /$ day. According to WHO guidelines, $10 \mathrm{~g}$ alcohol/ day is equivalent to one alcoholic beverage. Bottom 3 plots depict association between psychical activity and serum $\operatorname{IgA}, \operatorname{IgG}$, and $\operatorname{IgM}$ respectively with corresponding $95 \%$ confidence intervals. The associations have been adjusted for age, sex, BMI, smoking status, alcohol consumption, and hypertension. Psychical activity is depicted as standardized score of metabolic equivalent of task (MET) hours/ week. IgA, immunoglobulin A; IgG, immunoglobulin G; IgM, immunoglobulin M; BMI, body mass index; WHO, World Health Organization

of middle-aged and elderly individuals. We furthermore established references ranges of serum Igs in our cohort, both overall and stratified by identified relevant determinants. Reference ranges were $0.86-4.76 \mathrm{~g} / \mathrm{L}$ for $\mathrm{IgA}$, 6.20-15.10 g/L for IgG, and 0.28-2.64 g/L for IgM overall and were furthermore modified by age, sex, smoking status, and alcohol consumption.

IgA showed a J-shaped increase with age, while IgG gradually declined until the age of 60 years and started to increase afterwards. Previous population-based studies showed inconclusive results for the association of age with IgA and IgG, either reporting higher or similar levels at older age. However, these studies were much smaller than the current study, did not adjust for confounders, did not assess non-linearity of the association adequately, or categorized age in their analyses [22, 33-37]. Possible explanations for higher IgA and IgG levels at older age could be a higher 

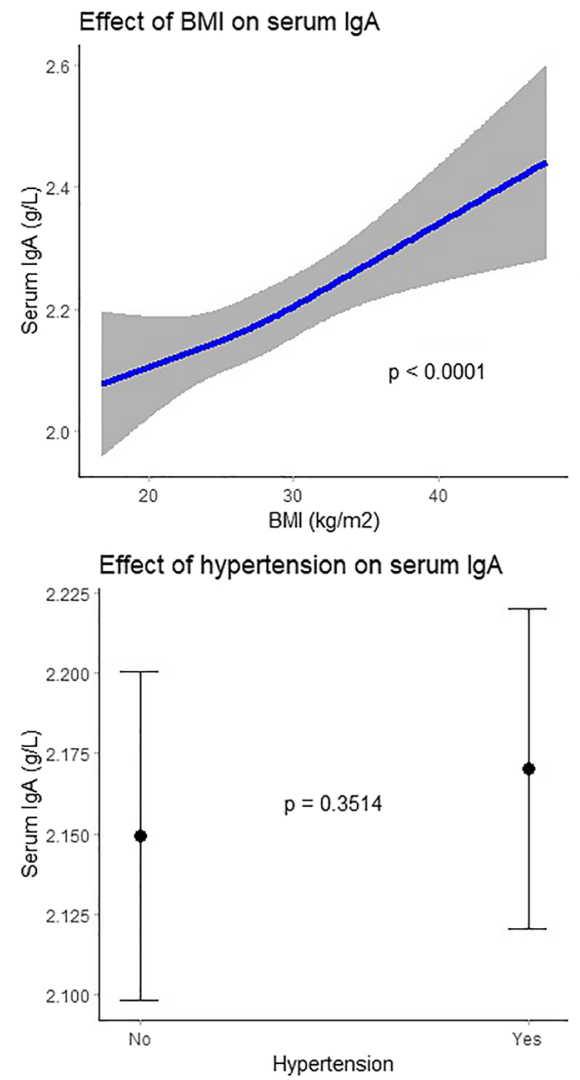

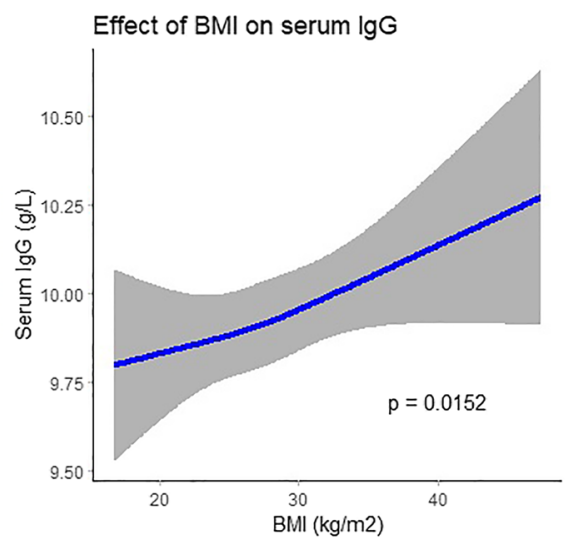

Effect of hypertension on serum IgG

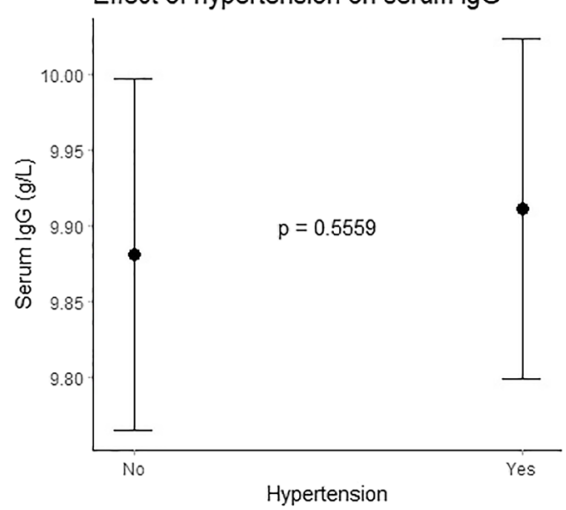

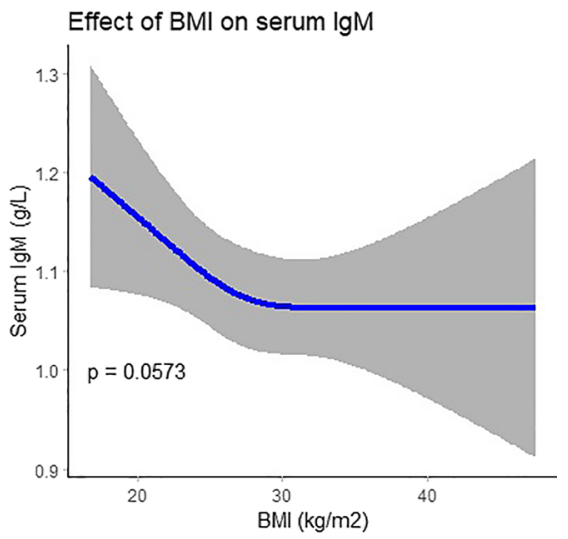

Effect of hypertension on serum IgM

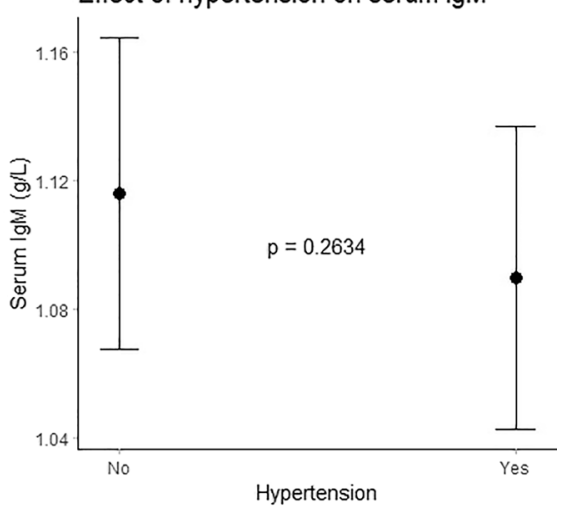

Fig. 3 Association between cardiovascular risk factors and serum immunoglobulin $(\mathrm{g} / \mathrm{L})$ levels. Top 3 plots depict association between BMI and serum IgA, IgG, and IgM respectively with corresponding 95\% confidence intervals. The associations have been adjusted for age, sex, smoking status, alcohol consumption, and hypertension. Bottom 3 plots depict association between hypertension and serum $\mathrm{IgA}, \mathrm{IgG}$, and IgM respectively with corresponding $95 \%$ confidence

ratio of memory to naïve B-cells [38], underlying conditions including rheumatic disorders, infections, or malignancies [7, 39], or monoclonal gammopathy of undetermined significance (MGUS), a highly prevalent disorder of aging [40]. However, higher serum Ig levels at older age could also reflect natural selection, i.e., participants with a better immune function having an increased life expectancy. Proteome analyses showed that healthy centenarians displayed upregulation of B-cell-mediated immune responses, including antibody production, compared to controls from the same geographical region that died prematurely [41].

We found higher $\operatorname{IgA}$ and $\operatorname{IgG}$, but lower IgM levels in men compared to women. The results for $\operatorname{IgA}$ and $\operatorname{IgM}$ are in line with our previous systematic review and meta-analysis and could be due to hormonal differences [26]. In vitro, application of estradiol to human lymphocytes increased B-cell differentiation and number of IgM-producing B-cells, while testosterone had no such effect [42]. Our finding of higher serum IgG levels in men could be explained by the relatively high age of participants in our cohort. Our intervals. The associations have been adjusted for age, sex, BMI, smoking status, and alcohol consumption. Hypertension was defined as a resting blood pressure of $\geq 140 / 90 \mathrm{~mm} \mathrm{Hg}$ or as use of blood pressure lowering agents with the indication of hypertension. $\operatorname{IgA}$, immunoglobulin A; IgG, immunoglobulin G; IgM, immunoglobulin M; BMI, body mass index

previous meta-analysis did not show an association between age and $\mathrm{IgG}$, but had included relatively small studies with generally much younger participants. Higher IgG levels in aging men could reflect an underlying inflammatory state. Inflammatory conditions such as cancer and chronic obstructive pulmonary disease are more common in men than women at older age [32].

We also found lower IgA and IgG levels in smokers compared to non-smokers. Nicotine stimulates immunosuppressive hormones including glucocorticoids and catecholamines and can negatively influence B-cell development and Ig production through suppression of the $\alpha 7$-subunit of nicotinic acetylcholine receptors expressed by T- and B-lymphocytes [43, 44]. We furthermore reported lower IgG levels in moderate and heavy alcohol consumers. Two previous population-based studies found similar results [22, 45], although some studies reported unchanged or higher IgG levels in relation to alcohol consumption [46, 47]. However, the latter two studies had small sample sizes $(n<60)$, and only assessed the effect of temporary alcohol admission (either a 
Table 3 Reference ranges of serum immunoglobulins (g/L) overall and stratified by determinants

\begin{tabular}{llll}
\hline & $\mathrm{IgA}^{\mathrm{a}}$ & $\mathrm{IgG}^{\mathrm{a}}$ & $\mathrm{IgM}^{\mathrm{a}}$ \\
Overall $(n=8768)$ & $0.86-4.76$ & $6.20-15.10$ & $0.28-2.64$ \\
\hline After exclusion of top 3 most burdensome diseases of elderly & \\
( $n=7016)$ & $0.86-4.69$ & $6.22-15.00$ & $0.29-2.60$ \\
Sex & & & \\
- Men $(n=3773)$ & $0.91-4.98$ & $6.30-15.10$ & $0.27-2.41$ \\
- Women $(n=4995)$ & $0.84-4.58$ & $6.10-15.10$ & $0.30-2.75$ \\
Age & & & \\
- $<65(n=5285)$ & $0.84-4.47$ & $6.20-14.70$ & $0.31-2.58$ \\
- $\geq 65(n=3483)$ & $0.90-5.30$ & $6.20-15.80$ & $0.26-2.79$ \\
Age categories & & & \\
- 45-50 $(n=488)$ & $0.86-4.24$ & $6.40-14.70$ & $0.32-2.62$ \\
- 50-55 ( $n=898)$ & $0.74-4.49$ & $6.70-15.41$ & $0.33-2.76$ \\
- 55-60 $(n=1927)$ & $0.84-4.56$ & $6.10-14.30$ & $0.30-2.44$ \\
- 60-65 $(n=1972)$ & $0.86-4.42$ & $6.12-14.80$ & $0.31-2.66$ \\
- 65-70 $(n=1134)$ & $0.94-4.85$ & $6.20-14.40$ & $0.28-2.66$ \\
- 70-75 ( $n=947)$ & $0.88-5.11$ & $5.90-15.10$ & $0.27-3.17$ \\
- 75-80 $(n=742)$ & $0.83-5.25$ & $6.30-16.40$ & $0.25-2.60$ \\
- 80-85 $(n=412)$ & $0.92-6.27$ & $5.76-17.17$ & $0.21-2.69$ \\
- $\geq 85(n=248)$ & $0.96-6.48$ & $6.75-19.99$ & $0.19-4.57$ \\
Smoking status & & & \\
- Never $(n=2901)$ & $0.86-4.94$ & $6.50-15.90$ & $0.29-2.53$ \\
- Former $(n=4155)$ & $0.87-4.79$ & $6.30-15.00$ & $0.28-2.68$ \\
- Current $(n=1712)$ & $0.81-4.35$ & $5.80-13.90$ & $0.27-2.73$ \\
Alcohol consumption & & & \\
- None $(n=1510)$ & $0.84-4.83$ & $6.00-16.03$ & $0.27-2.80$ \\
- Mild $(0-10$ g/day) $(n=4673)$ & $0.84-4.69$ & $6.30-15.10$ & $0.29-2.66$ \\
- Moderate $(10-20$ g/day) & & & \\
$(n=1456)$ & $0.87-4.65$ & $6.14-14.40$ & $0.28-2.57$ \\
- Heavy (>20 g/day) $(n=1129)$ & $0.98-5.13$ & $6.10-14.76$ & $0.27-2.46$ \\
\hline & & & \\
\hline
\end{tabular}

$I g A$, immunoglobulin $\mathrm{A} ; \operatorname{Ig} G$, immunoglobulin $\mathrm{G} ; \operatorname{Ig} M$, immunoglobulin M

${ }^{\text {a }}$ Reference ranges are 2.5 th-97.5th percentiles

${ }^{\mathrm{b}}$ Comprises cardiovascular disease (myocardial infarction, revascularization, stroke), cancer, and chronic obstructive pulmonary disease

${ }^{\mathrm{c}} 10 \mathrm{~g}$ alcohol/day is equivalent to one alcoholic beverage according to World Health Organization guidelines

few hours or weeks) on serum Ig levels. In vitro and in vivo experiments showed that alcohol consumption either stimulates or inhibits lymphocytes depending on the duration and dose of consumption [48].

We confirmed BMI, waist circumference, serum HDL cholesterol, serum triglycerides, and systemic corticosteroid use as determinants $[22,49,50]$ and identified total serum cholesterol and serum CRP as new determinants. Metabolic abnormalities such as obesity, a sedentary lifestyle, and elevated serum lipids have been linked to inflammation through various possible pathways including overexpression of inflammatory markers (e.g., tumor necrosis factor $\alpha)$ in adipose tissue and activation of inflammatory kinases by lipids [51]. The immunosuppressive effects of systemic corticosteroids are well recognized and several mechanisms have been described, including reduction in the absolute numbers of circulating T- and B-cells and altered gene transcription in leukocytes, leading to terminal differentiation defects and reduced proliferation of B-cells, impaired B-cell receptor signaling, and reduced expression of all three human Ig loci among others [52, 53]. Higher Ig levels with higher CRP levels could be due to the fact that both reflect an inflammatory state and CRP can be produced by lymphocytes as well [54].

Interestingly, many determinants displayed a similar direction of association with $\operatorname{IgA}$ and $\mathrm{IgG}$, suggesting that there may be an effect on immunoglobulin class switch (IgCS). Lipopolysaccharide (LPS) is a well-known inducer of $\operatorname{IgCS}$ [55]. Serum LPS is recognized and bound by lipopolysaccharide-binding protein (LBP) [56]. In Caucasians, higher LBP levels were associated with higher BMI, waist-to-hip ratio, and serum glucose and CRP levels, but lower HDL cholesterol levels [57, 58]. Older participants had higher LBP levels as well [58], whereas exercise was associated with a reduction in LBP [59]. Assuming more IgCS in participants with higher LBP levels, these findings are in line with the associations we report for age, cardiovascular risk factors, and physical activity with serum IgA and $\mathrm{IgG}$.

Our age- and sex-specific reference ranges were in line with the reported associations of age and sex with serum Igs. Furthermore, reference ranges of current smokers were lower for $\operatorname{IgA}$ and predominantly for $\operatorname{IgG}$ than those of former and never smokers. This difference was more apparent in women than in men. Although studies on sex differences in the pharmacodynamics of nicotine are inconclusive, some studies in rats and humans have shown that women metabolize nicotine more slowly and are more sensitive to its effects than men [60].

Our findings urge the application of age- and sex-specific reference ranges of serum Igs in middle-aged and elderly individuals. In our population of healthy elderly, we found lower reference ranges for serum IgG compared to the assay's recommended reference ranges in adults, yielding fewer participants with hypogammaglobulinemia. This may have important implications for the diagnosis of PIDs at older age, since lower IgG levels represent a physiological rather than pathological state in this population. On the other hand, the threshold for high $\mathrm{IgG}$ levels decreases as well, warranting earlier work-up for inflammatory conditions. Current smokers and systemic corticosteroid users had $>1 \mathrm{~g} / \mathrm{L}$ lower IgG levels compared to non-smokers and non-users of systemic corticosteroids respectively. This is important to take into account for clinicians treating patients with PIDs. It may be advisable to refrain from (long-term) 


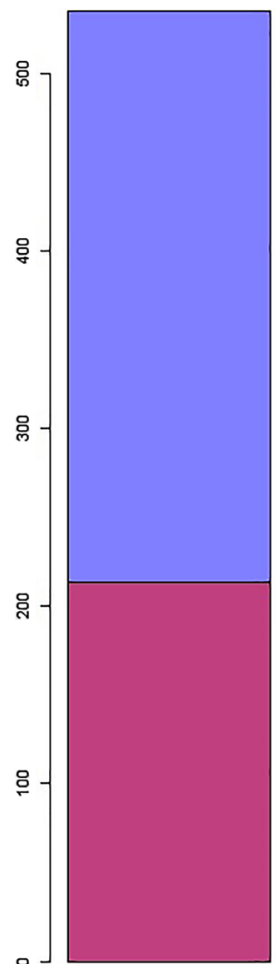

IgA high

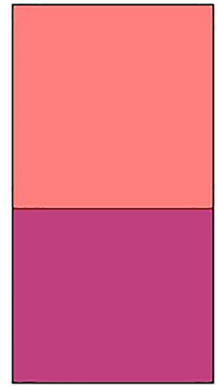

IgA low

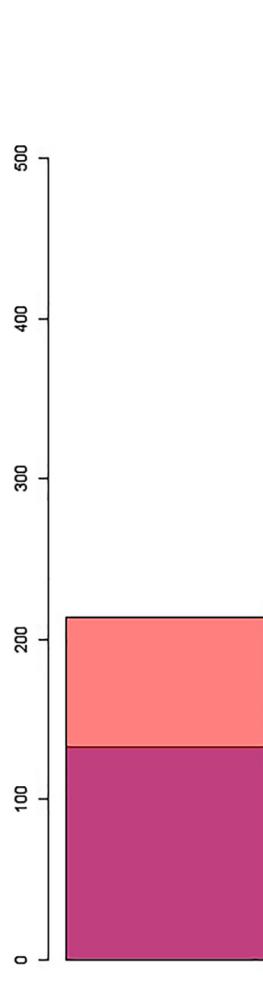

IgG high

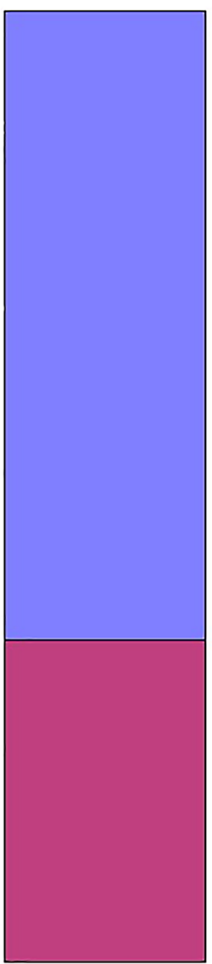

IgG low

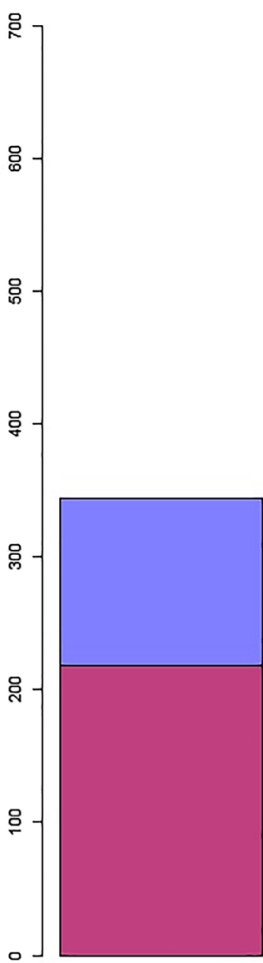

Igll high

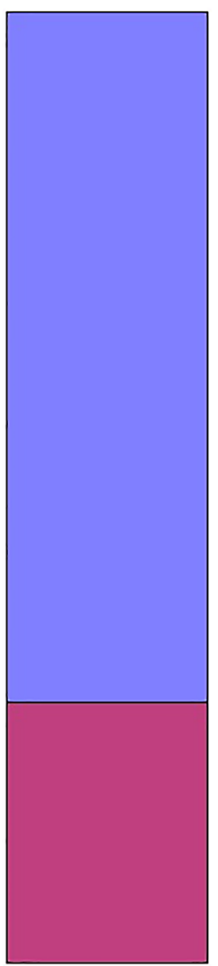

Igllow
Fig. 4 Number of participants with low or high serum immunoglobulin levels according to different reference ranges. Blue depicts the number of participants with serum immunoglobulin levels outside the reference range as recommended by the assay's manufacturer. Orange depicts the number of participants with serum immunoglobulin lev- els outside the reference range as computed by us for this population. Red depicts the overlay in participants with low or high immunoglobulin levels according to both reference ranges. IgA, immunoglobulin A; IgG, immunoglobulin G; IgM, immunoglobulin M

Table 4 Misclassification of low or high serum immunoglobulin levels according to assay recommended vs Rotterdam Study population specific reference ranges

\begin{tabular}{|c|c|c|c|c|c|c|}
\hline & \multicolumn{2}{|c|}{$\operatorname{Ig} A$} & \multicolumn{2}{|c|}{ IgG } & \multicolumn{2}{|c|}{ IgM } \\
\hline & $\underline{\mathrm{N} \text { in assay }}$ & N out assay & $\underline{\mathrm{N} \text { in assay }}$ & $\underline{N}$ out assay & $\underline{N}$ in assay & N out assay \\
\hline $\mathrm{N}$ in specific & 8,019 & 321 & 7,950 & 392 & 7,704 & 645 \\
\hline N out specific & 115 & 312 & 81 & 334 & 0 & 414 \\
\hline
\end{tabular}

Numbers depict participants with immunoglobulin levels inside or outside the reference range as recommended by the assay's manufacturer (0.7-4.0 g/L for $\operatorname{IgA}, 7.0-16.0 \mathrm{~g} / \mathrm{L}$ for $\mathrm{IgG}$, and $0.4-2.3 \mathrm{~g} / \mathrm{L}$ for $\mathrm{IgM})$ or as calculated in our study population $(0.86-4.76 \mathrm{~g} / \mathrm{L}$ for $\mathrm{IgA}$, 6.20$15.10 \mathrm{~g} / \mathrm{L}$ for $\mathrm{IgG}$, and $0.28-2.64 \mathrm{~g} / \mathrm{L}$ for $\mathrm{IgM}$ )

Green cells display correspondence between reference ranges, while orange cells display discrepancy

$I g A$, immunoglobulin $\mathrm{A} ; \operatorname{Ig} G$, immunoglobulin $\mathrm{G} ; \operatorname{Ig} M$, immunoglobulin $\mathrm{M}$

treatment with systemic corticosteroids in a population already struggling with low IgG levels. Alternatively, if such treatment is inevitable, adjustment of intravenous Ig (IVIG) dosage or closer follow-up of serum IgG levels may be suggested. Furthermore, lifestyle changes seem an interesting addition to the treatment of PID patients. Former smokers had a less strong decline in serum IgG than current smokers, suggesting that quitting smoking may have a beneficial influence on serum IgG levels in PID patients as well.
To our knowledge, we are the first to assess the association of various potential determinants and serum Igs in a large population-based cohort of middle-aged and elderly participants. We corrected for a wide number of confounders and displayed non-linear associations of determinants and serum Igs visually. We furthermore provided subgroup-specific reference ranges based on identified determinants. To ensure a healthy study population, we assessed the influence of excluding the top three most burdensome diseases in the elderly. However, our study has 
some limitations. The RS consists of a mainly Caucasian population; therefore, results might not be generalizable to other populations. Furthermore, we did not have repeated measurements of serum Igs and could not assess potential bidirectional associations with determinants. Moreover, we did not have information on the prevalence of MGUS in our study cohort, which could have an impact on our results, as MGUS is common in the elderly population with an estimated prevalence of $5.3 \%$ in individuals aged 70 years and over. Furthermore, translational research is needed to provide more insights into the immunomodulating properties of identified determinants and to provide robust recommendations for clinical practice, including the association between determinants and vaccine or other functional antibody responses. While we assessed the association between determinants and serum immunoglobulins, factors associated with detailed immunophenotyping within the general population could be of future interest as well.

\section{Conclusion}

Age, sex, smoking status, alcohol consumption, corticosteroid use, and cardiovascular factors influence serum immunoglobulin levels in middle-aged and elderly individuals from the general population. Subsequently, our results suggest that currently applied clinical reference values of $\operatorname{IgA}, \operatorname{IgG}$, and $\operatorname{IgM}$ in adults should be adapted for specific subgroups.

Supplementary Information The online version contains supplementary material available at https://doi.org/10.1007/s10875-021-01120-5.

Acknowledgements The authors are grateful to the study participants, the staff of the Rotterdam Study, and the participating general practitioners and pharmacists.

Author Contribution Conceptualization: Samer R. Khan, Layal Chaker, Robin P. Peeters, P. Martin van Hagen, Virgil A.S.H Dalm;

Data curation: M. Arfan Ikram;

Methodology: Samer R. Khan, Layal Chaker;

Formal analysis and Investigation: Samer R. Khan;

Writing - original draft preparation: Samer R. Khan;

Writing - review and editing: Samer R. Khan, Layal Chaker, M. Arfan Ikram, Robin P. Peeters, P. Martin van Hagen, Virgil A.S.H Dalm;

Supervision: Layal Chaker, Robin P. Peeters, P. Martin van Hagen, Virgil A.S.H. Dalm;

Funding acquisition: M. Arfan Ikram, Virgil A.S.H. Dalm.

Funding The Rotterdam Study is funded by Erasmus Medical Center and Erasmus University, Rotterdam, Netherlands Organization for the Health Research and Development (ZonMw), the Research Institute for Diseases in the Elderly (RIDE), the Ministry of Education, Culture and Science, the Ministry for Health, Welfare and Sports, the European Commission (DG XII), and the Municipality of Rotterdam.

Virgil A.S.H Dalm received an unrestricted investigator-initiated research grant from Takeda Pharmaceutical Company Limited (IIR-NLD-002671).

Availability of Data and Material The datasets generated during and/ or analyzed during the current study are not publicly available due to participant confidentiality agreements.

Code Availability Statistical software codes are available from the corresponding author on reasonable request.

\section{Declarations}

Conflict of Interest The authors declare no competing interests.

Ethics Approval This study was performed in line with the principles of the Declaration of Helsinki. Approval was granted by the Medical Ethics Committee of Erasmus University Medical Center (registration number MEC 02.1015) and by the Dutch Ministry of Health, Welfare and Sport (Population Screening Act WBO, license number 1071272-159521-PG). The Rotterdam Study Personal Registration Data collection is filed with the Erasmus University Medical Center Data Protection Officer under registration number EMC1712001. The Rotterdam Study has been entered into the Netherlands National Trial Register and into the World Health Organization International Clinical Trials Registry Platform under shared catalogue number NTR6831.

Consent to Participate Written informed consent was obtained from all individual participants included in the study.

Consent for Publication Not applicable as this study concerns population-based data with no identifying information about participants.

Open Access This article is licensed under a Creative Commons Attribution 4.0 International License, which permits use, sharing, adaptation, distribution and reproduction in any medium or format, as long as you give appropriate credit to the original author(s) and the source, provide a link to the Creative Commons licence, and indicate if changes were made. The images or other third party material in this article are included in the article's Creative Commons licence, unless indicated otherwise in a credit line to the material. If material is not included in the article's Creative Commons licence and your intended use is not permitted by statutory regulation or exceeds the permitted use, you will need to obtain permission directly from the copyright holder. To view a copy of this licence, visit http://creativecommons.org/licenses/by/4.0/.

\section{References}

1. Späth PJ. Structure and function of immunoglobulins. Sepsis. 1999;3(3):197-218.

2. Oksenhendler E, Gerard L, Fieschi C, Malphettes M, Mouillot G, Jaussaud R, et al. Infections in 252 patients with common variable immunodeficiency. Clin Infect Dis. 2008;46(10):1547-54.

3. Fischer A, Provot J, Jais JP, Alcais A, Mahlaoui N, members of the CFPIDsg. Autoimmune and inflammatory manifestations occur frequently in patients with primary immunodeficiencies. J Allergy Clin Immunol. 2017;140(5):1388-93 e8.

4. Bonilla FA, Barlan I, Chapel H, Costa-Carvalho BT, Cunningham-Rundles C, de la Morena MT, et al. International Consensus 
Document (ICON): common variable immunodeficiency disorders. J Allergy Clin Immunol Pract. 2016;4(1):38-59.

5. Resnick ES, Moshier EL, Godbold JH, Cunningham-Rundles C. Morbidity and mortality in common variable immune deficiency over 4 decades. Blood. 2012;119(7):1650-7.

6. Gathmann B, Mahlaoui N, Ceredih, Gerard L, Oksenhendler E, Warnatz K, et al. Clinical picture and treatment of 2212 patients with common variable immunodeficiency. J Allergy Clin Immunol. 2014;134(1):116-26.

7. Dispenzieri A, Gertz MA, Therneau TM, Kyle RA. Retrospective cohort study of 148 patients with polyclonal gammopathy. Mayo Clin Proc. 2001;76(5):476-87.

8. Oliveira JB, Fleisher TA. Laboratory evaluation of primary immunodeficiencies. J Allergy Clin Immunol. 2010;125(2 Suppl 2):S297-305.

9. Ameratunga R, Woon ST, Gillis D, Koopmans W, Steele R. New diagnostic criteria for common variable immune deficiency (CVID), which may assist with decisions to treat with intravenous or subcutaneous immunoglobulin. Clin Exp Immunol. 2013;174(2):203-11.

10. Alexander RL Jr. Comparison of radial immunodiffusion and laser nephelometry for quantitating some serum proteins. Clin Chem. 1980;26(2):314-7.

11. Blanchard GC, Gardner R. Two nephelometric methods compared with a radial immunodiffusion method for the measurement of IgG. IgA and IgM Clin Biochem. 1980;13(2):84-91.

12. Normansell DE. Quantitation of serum immunoglobulins. Crit Rev Clin Lab Sci. 1982;17(2):103-70.

13. Ahmed J, Zaman MM, Rouf MA, Mm MH, Zareen S. Reference value of immunoglobulins in healthy school children of Bangladesh. J Epidemiol. 2001;11(6):263-5.

14. Irjala K, Koskinen P, Icen A, Palosuo T. Reference intervals for immunoglobulins IgA, IgG and IgM in serum in adults and in children aged 6 months to 14 years. Scand J Clin Lab Invest. 1990;50(5):573-7.

15. Puissant-Lubrano B, Peres M, Apoil P-A, Congy-Jolivet N, Roubinet F, Blancher A. Immunoglobulin IgA, IgD, IgG, IgM and IgG subclass reference values in adults. Clinical Chemistry and Laboratory Medicine (CCLM). 2015;53(12):e359-61.

16. Jolliff CR, Cost KM, Stivrins PC, Grossman PP, Nolte CR, Franco SM, et al. Reference intervals for serum IgG, IgA, IgM, $\mathrm{C} 3$, and $\mathrm{C} 4$ as determined by rate nephelometry. Clin Chem. 1982;28(1):126-8.

17. Lock RJ, Unsworth DJ. Immunoglobulins and immunoglobulin subclasses in the elderly. Ann Clin Biochem. 2003;40(2):143-8.

18. Kruger A. 1 The limits of normality in elderly patients. Bailliere's clinical haematology. 1987;1(2):271-89.

19. Challacombe SJ, Percival RS, Marsh PD. Age-related changes in immunoglobulin isotypes in whole and parotid saliva and serum in healthy individuals. Oral Microbiol Immunol. 1995;10(4):202-7.

20. De Greef GE, Van Tol MJD, Van Den Berg JWK, Van Staalduinen GJ, Janssen CJ, Radl J, et al. Serum immunoglobulin class and IgG subclasses levels and the occurrence of homogeneous immunoglobulins during the course of ageing in humans. Mech Ageing Dev. 1992;66(1):29-44

21. Veys EM, Wieme RJ. Serum IgG, IgM and IgA concentration determined by the "linear plate" immunodiffusion technique in a normal population. Clin Chim Acta. 1973;47(2):295-306.

22. Gonzalez-Quintela A, Alende R, Gude F, Campos J, Rey J, Meijide LM, et al. Serum levels of immunoglobulins (IgG, IgA, IgM) in a general adult population and their relationship with alcohol consumption, smoking and common metabolic abnormalities. Clin Exp Immunol. 2008;151(1):42-50.

23. Svalheim S, Mushtaq U, Mochol M, Luef G, Rauchenzauner M, Frøland SS, et al. Reduced immunoglobulin levels in epilepsy patients treated with levetiracetam, lamotrigine, or carbamazepine. Acta Neurol Scand. 2013;127:11-5.

24. Settipane GA, Pudupakkam RK, McGowan JH. Corticosteroid effect on immunoglobulins. Journal of Allergy and Clinical Immunology. 1978;62(3):162-6.

25. Córdova A, Sureda A, Tur JA, Pons A. Immune response to exercise in elite sportsmen during the competitive season. J Physiol Biochem. 2010;66(1):1-6.

26. Khan SR, van der Burgh AC, Peeters RP, van Hagen PM, Dalm VASH, Chaker L. Determinants of serum immunoglobulin levels: a systematic review and meta-analysis. Frontiers in Immunology. 2021;12(1103).

27. Ikram MA, Brusselle G, Ghanbari M, Goedegebure A, Ikram MK, Kavousi M, et al. Objectives, design and main findings until 2020 from the Rotterdam Study. European Journal of Epidemiology. 2020:1-35

28. Dati F, Schumann G, Thomas L, Aguzzi F, Baudner S, Bienvenu J, et al. Consensus of a group of professional societies and diagnostic companies on guidelines for interim reference ranges for 14 proteins in serum based on the standardization against the IFCC/BCR/CAP Reference Material (CRM 470). International Federation of Clinical Chemistry. Community Bureau of Reference of the Commission of the European Communities. College of American Pathologists. Eur J Clin Chem Clin Biochem. 1996;34(6):517-20.

29. Caspersen CJ, Bloemberg BPM, Saris WHM, Merritt RK, Kromhout D. The prevalence of selected physical activities and their relation with coronary heart disease risk factors in elderly men: the Zutphen Study, 1985. Am J Epidemiol. 1991;133(11):1078-92.

30. Stel VS, Smit JH, Pluijm SMF, Visser M, Deeg DJH, Lips P. Comparison of the LASA Physical Activity Questionnaire with a 7-day diary and pedometer. J Clin Epidemiol. 2004;57(3):252-8.

31. Wright EM, Royston P. Calculating reference intervals for laboratory measurements. Stat Methods Med Res. 1999;8(2):93-112.

32. Prince MJ, Wu F, Guo Y, Robledo LMG, O’Donnell M, Sullivan $\mathrm{R}$, et al. The burden of disease in older people and implications for health policy and practice. The Lancet. 2015;385(9967):549-62.

33. Cassidy JT, Nordby GL, Dodge HJ. Biologic variation of human serum immunoglobulin concentrations: sex-age specific effects. J Chronic Dis. 1974;27(11-12):507-16.

34. Yodfat Y, Keren L, Zlotnick A. Serum immunoglobulin levels in healthy adults of various ethnic groups in a rural family practice in Israel. J Fam Pract. 1975;2(6):419-22.

35. Maddison SE, Stewart CC, Farshy CE, Reimer CB. The relationship of race, sex, and age to concentrations of serum immunoglobulins expressed in international units in healthy adults in the USA. Bull World Health Organ. 1975;52(2):179.

36. Stoica G, Macarie E, Michiu V, Stoica RC. Biologic variation of human immunoglobulin concentration. I. Sex-age specific effects on serum levels of $\operatorname{IgG}, \operatorname{IgA}, \operatorname{IgM}$ and $\operatorname{IgD}$. Medecine interne. 1980;18(3):323-32.

37. Quintiliani L, Taggi F, Giuliani E, Buzzonetti A, D'Amico F. $\mathrm{IgG}, \mathrm{IgA}$ and $\mathrm{IgM}$ concentration in human sera from different age groups: statistical evaluation. Boll Ist Sieroter Milan. 1976;55(3):241-8.

38. Ongrádi J, Kövesdi V. Factors that may impact on immunosenescence: an appraisal. Immunity \& ageing. 2010;7(1):1-14.

39. Yang Y, Chen L, Jia Y, Liu Y, Wen L, Liang Y, et al. Monoclonal gammopathy in rheumatic diseases. Clin Rheumatol. 2018;37(7):1751-62.

40. Guerard EJ, Tuchman SA. Monoclonal Gammopathy of undetermined significance and multiple myeloma in older adults. Clin Geriatr Med. 2016;32(1):191-205.

41. Santos-Lozano A, Valenzuela PL, Llavero F, Lista S, CarreraBastos P, Hampel H, et al. Successful aging: insights from 
proteome analyses of healthy centenarians. Aging (Albany NY). 2020;12(4):3502-15.

42. Paavonen T, Andersson LC, Adlercreutz H. Sex hormone regulation of in vitro immune response. Estradiol enhances human B cell maturation via inhibition of suppressor $\mathrm{T}$ cells in pokeweed mitogen-stimulated cultures. The Journal of experimental medicine. 1981;154(6):1935-45.

43. McAllister-Sistilli CG, Caggiula AR, Knopf S, Rose CA, Miller AL, Donny EC. The effects of nicotine on the immune system. Psychoneuroendocrinology. 1998;23(2):175-87.

44. Kawashima K, Fujii T, Moriwaki Y, Misawa H. Critical roles of acetylcholine and the muscarinic and nicotinic acetylcholine receptors in the regulation of immune function. Life Sci. 2012;91(21-22):1027-32.

45. Liao M, Ye F, Zhang B, Huang L, Xiao Q, Qin M, et al. Genomewide association study identifies common variants at TNFRSF13B associated with $\mathrm{IgG}$ level in a healthy Chinese male population. Genes Immun. 2012;13(6):509-13.

46. Romeo J, Wärnberg J, Nova E, Díaz LE, González-Gross M, Marcos A. Changes in the immune system after moderate beer consumption. Ann Nutr Metab. 2007;51(4):359-66.

47. De Feo P, Volpi E, Lucidi P, Cruciani G, Monacchia F, Reboldi G, et al. Ethanol impairs post-prandial hepatic protein metabolism. J Clin Investig. 1995;95(4):1472-9.

48. Barr T, Helms C, Grant K, Messaoudi I. Opposing effects of alcohol on the immune system. Prog Neuropsychopharmacol Biol Psychiatry. 2016;65:242-51.

49. Van Schoor J, Toogood JH, Pauwels RA. Differential effects of inhaled budesonide and oral prednisolone on serum immunoglobulin $\mathrm{G}$ and its subclasses in healthy adult volunteers. Clin Exp Allergy. 1997;27(2):192-5.

50. Butler WT, Rossen RD. Effects of corticosteroids on immunity in man I. Decreased serum IgG concentration caused by 3 or 5 days of high doses of methylprednisolone. The Journal of clinical investigation. 1973;52(10):2629-40.

51. Hotamisligil GS. Inflammation and metabolic disorders. Nature. 2006;444(7121):860-7.
52. Coutinho AE, Chapman KE. The anti-inflammatory and immunosuppressive effects of glucocorticoids, recent developments and mechanistic insights. Mol Cell Endocrinol. 2011;335(1):2-13.

53. Franco LM, Gadkari M, Howe KN, Sun J, Kardava L, Kumar $\mathrm{P}$, et al. Immune regulation by glucocorticoids can be linked to cell type-dependent transcriptional responses. J Exp Med. 2019;216(2):384-406.

54. Sproston NR, Ashworth JJ. Role of C-reactive protein at sites of inflammation and infection. Front Immunol. 2018;9:754.

55. Stavnezer J. Immunoglobulin class switching. Curr Opin Immunol. 1996;8(2):199-205.

56. Tuomi K, Logomarsino JV. Bacterial lipopolysaccharide, lipopolysaccharide-binding protein, and other inflammatory markers in obesity and after bariatric surgery. Metab Syndr Relat Disord. 2016;14(6):279-88.

57. Moreno-Navarrete JM, Ortega F, Serino M, Luche E, Waget A, Pardo G, et al. Circulating lipopolysaccharide-binding protein (LBP) as a marker of obesity-related insulin resistance. Int J Obes (Lond). 2012;36(11):1442-9.

58. Gonzalez-Quintela A, Alonso M, Campos J, Vizcaino L, Loidi L, Gude F. Determinants of serum concentrations of lipopolysaccharide-binding protein (LBP) in the adult population: the role of obesity. PLoS One. 2013;8(1):e54600.

59. Motiani KK, Collado MC, Eskelinen JJ, Virtanen KA, E LO, Salminen S, et al. Exercise training modulates gut microbiota profile and improves endotoxemia. Med Sci Sports Exerc. 2020;52(1):94-104.

60. Pogun S, Yararbas G. Sex differences in nicotine action. Nicotine psychopharmacology: Springer; 2009. p. 261-91.

Publisher's Note Springer Nature remains neutral with regard to jurisdictional claims in published maps and institutional affiliations. 